\title{
Imaging the God of Justice and Mercy: Theological Allusions in John Wesley's Thoughts upon Slavery
}

\author{
David N. Field \\ https://orcid.org/0000-0001-6744-1482 \\ University of South Africa \\ davidnfield@protonmail.com
}

\begin{abstract}
John Wesley's influential booklet, Thoughts upon Slavery, argues that slavery is inherently evil and ought to be abolished, largely using the non-religious language of justice, mercy, natural liberty, and natural law. In key places in his argument Wesley alludes to theological concepts. This article contends that these allusions are not random but refer to key theological components of the core of Wesley's theology. It relates these allusions to expositions of the core concepts in Wesley's other writings to argue that slavery, and other forms of social injustice, are inherently incompatible with the core of Wesleyan theology.
\end{abstract}

Keywords: John Wesley; slavery; social justice; Wesleyan ethics; Wesleyan theology

\section{UNISA $\cong$}

Studia Historiae Ecclesiasticae https://upjournals.co.za/index.php/SHE/index Volume 47 | Number 1 | 2021 | \#8466 | 20 pages https://doi.org/10.25159/2412-4265/8466 ISSN 2412-4265(Online)ISSN 1017-0499(Print)

(C) The Author(s) 2021 


\section{Introduction}

In June 2020, Black Lives Matter protesters pulled down the statue of Bristol city benefactor, merchant and slave trader, Edward Carlston, and cast it into Bristol Harbour. This was not the first protest against slavery in Bristol. It was here that the 84-year-old John Wesley preached against slavery in 1788 . He described the dramatic events:

... the house from end to end was filled with high and low, rich and poor. ... About the middle of the discourse while there was on every side attention [still] as night, a vehement storm arose, none could tell why, and shot like lightening through the whole congregation. The terror and confusion were inexplicable. You might have imagined it was a city taken by storm. The people rushed upon each other with the utmost violence, the benches were broken in pieces, and nine-tenths of the congregation appeared struck with same panic. (Wesley 2003, 70)

Bristol was not only the centre of the British slave trade, but it was also an important centre of early Methodism. George Whitefield requested John Wesley to come to Bristol in 1739, and in response to Whitefield's urging he began to preach to the poor and marginalised in the open air. Methodists and other descendants of the eighteenthcentury evangelical revival have pointed with pride to John Wesley's opposition to slavery in the city whose wealth was built on slavery. George Whitefield's entanglements with slavery have become an embarrassment. In July 2020, Pennsylvania State University announced it would be removing its statue of George Whitefield. Whitefield opposed the slave trade and the cruel treatment of enslaved people but defended the institution of slavery; he owned enslaved people, advocated for the introduction of slavery into Georgia, and argued that the ownership of enslaved people by Christians could be a means of evangelism (Brendlinger 2006a, 56-58; O'Brien 2018).

One could speculate on the diverse factors that led these two influential leaders in the evangelical revival to opposing viewpoints on one of the fundamental injustices of the eighteenth century. Given that Wesley's position was a minority viewpoint in the religious world of eighteenth-century Britain, a more fruitful investigation would be to examine the relationship between John Wesley's opposition to slavery and his core theological commitments.

Unfortunately, no manuscript of Wesley's sermon against slavery has survived. However, he set out his argument against slavery in his 1774 booklet, Thoughts upon Slavery (Wesley 2007b, 59-79). ${ }^{1}$ This is a work of nascent public theology, whose central argument is framed in the non-religious language of natural rights and liberty (Field 2015). Despite Wesley's use of non-religious language, there are significant

1 All references to Thoughts upon Slavery are to this edition. I have retained the inconsistent capitalisation found in this edition. The 1774 edition is available online at: https://books.google.ch/books?id=D6s-

AQAAMAAJ\&printsec=frontcover\&source=gbs_ge_summary_r\&cad=0\#v=onepage\&q $\& \mathrm{f}=\mathrm{false}$. 
allusions to theological themes within the text. More importantly, these allusions relate directly to key themes in Wesley's core theological commitments. People unfamiliar with Wesley's writings would have read the tract as a primarily non-religious argument, while his followers would have discerned greater theological depth that underlay his argument. In this section we will explore these allusions by relating them to Wesley's core theological convictions and to the way they are developed in his other writings. ${ }^{2}$

\section{John Wesley's Core Theological Convictions in Outline}

In order to understand the allusions in Thoughts upon Slavery, the following themes from Wesley's theology are significant. ${ }^{3}$

God is love. Wesley wrote "love in the abstract, without bounds; and "there is no end of his goodness"” (Wesley 2013, 285). God the "the great ocean of love" (Wesley 1985,

2 The particular contribution of this article to understanding John Wesley's opposition to slavery lies in this reading of the theological allusions in Thoughts upon Slavery. This can be seen by a brief overview of some of the key secondary literature. Warren Smith's John Wesley and Slavery provides detailed information on Wesley's encounter with slavery and his opposition to it, but merely provides a summary of Thoughts upon Slavery and does not relate this to his theology (Smith 1986). Manfred Marquardt, in John Wesley's Social Ethics: Praxis and Principles, has a chapter summarising Wesley's opposition to slavery as one of a number of social issues that he addressed. The final section of his book addresses the theology that underlies Wesley's social ethics. This is not related directly to his opposition to slavery or his argument in Thoughts upon Slavery (Marquardt 199267-76 \& 87-132). Ronald Stone, in John Wesley's Life and Ethics, devotes a chapter to Wesley's opposition to slavery and interprets the ethical approach of Thoughts upon Slavery as primarily a natural law ethic; neither in this chapter nor the concluding remarks on Wesley's ethics does he relate this to the core themes of Wesley's theology (Stone 2001,187-197 \& 208-228).

Two texts do devote considerable attention to the relationship between Wesley's theology and his opposition to slavery. Irva Brendlinger, in his Social Justice through the Eyes of Wesley, provides a detailed summary of key aspects of Wesley's theology and then addresses how they influence his approach to slavery. The theological themes he refers to are human nature, prevenient grace, free will, and Christian perfection (Brendlinger 2006a, 73-128). There is some overlap in the content of Brendlinger's discussion and what follows here; however, the approach is different. He expounds key themes and then shows how they relate to Wesley's argument against slavery. In doing so, he does not give detailed attention to the theological allusions as keys to interpreting the relationship between Wesley's theology and his opposition to slavery. Also, he does not address all the interrelationships between Wesley's theology and his opposition to slavery. In the argument below, I address a number of themes that Brendlinger does not address. This article complements Brendlinger thematically, but does so from a different methodological starting point.

The second text that addresses the relationship between Wesley's theology and his opposition to slavery, is that of Joseph Suray, Towards a Theology of Universality. Suray discusses Wesley's understanding of God, humanity, prevenient grace, atonement, fellowship, equality, and justice. In a way that is similar to Brendlinger, he expounds the themes and then relates them to social issues, including slavery (Suray 2015, 127-246). Methodologically this differs from the approach of this article by starting with broad theological themes rather than a close reading of the text of Thoughts upon Slavery, and thus does not include some of the key themes developed below. Hence this article also complements Suray's work.

3 For detailed analyses of Wesley's theology, see Maddox 1994, and Collins 2007. 
39) loves all the creatures that God has made. Wesley regularly used Psalm 145:9, "The LORD is good to all and his tender mercies are over all his works," to express this.

God created human beings in the image of God. The image has two aspects - the natural image and the moral image. ${ }^{4}$ The natural image is composed of the understanding, the will, and liberty. The moral image is the reflection of God's moral character of love. God's purpose in creating human beings was that they should be happy (Wesley 1987a, 63).

Human beings turned away from God and centred their lives on themselves. Wesley describes the self-centred life as characterised by pride and self-will. In doing so, the natural image of God is severely distorted and the moral image is lost.

God is present and active in all human beings in prevenient grace, partially restoring the image of God. This enables human beings to make responsible moral decisions and it gives all human beings an awareness of God's moral requirements and the limited ability to practise them. This is not a static restoration. As human beings respond positively to God's active presence, they grow in their awareness of and ability to fulfil God's moral requirements; if they reject God's active presence, they decline in their ability to know and conform to God's requirements.

Jesus Christ reveals God's moral requirements more fully and proclaims God's gracious way of fulfilling these requirements. Through faith in Christ, God forgives a person's sin and gives them the new birth which is a fuller restoration of the image of God. The new birth empowers human beings to live out God's moral requirements. This begins the process of sanctification through which the restoration of the image of God is deepened and broadened. Sanctification reaches a further culmination point in Christian perfection, through which a person's life becomes permeated by the divine love.

God will judge all human beings with justice; hence all human beings are responsible for their actions and will account for them to God.

\section{Wesley's Argument in Thoughts upon Slavery}

Thoughts upon Slavery is a coherent argument that slavery is inherently unjust, cruel and immoral. ${ }^{5}$ Slavery cannot be improved, it has to be rejected.

The first section of the booklet is a rejection of the argument that European slave traders rescued Africans from barbaric and degraded cultures. Wesley portrays West-African societies - before the slave trade - as being prosperous societies characterised by

4 In a few places Wesley refers to a threefold image, adding the "political image," see Wesley 1985, 188 and 2012, 355. Wesley's use of a threefold image is based on the work of Isaac Watts, and the second reference is extracted from Watt's The Ruin and Recovery of Mankind.

5 Wesley drew extensively on other sources but the core of the argument is his own; see Baker 1984. 
compassion, justice, integrity, peace, and prosperity (Wesley 2007b, 60-65). Furthermore, he affirms that this was rooted in the people's worship of God through traditional African religions or Islam. He concludes by asking: "Where shall we find at this day, among the fair-faced natives of Europe, a nation generally practicing the justice, mercy, and truth, which are found among these poor Africans?" (Wesley 2007b, $65)$.

The next section describes the cruelty of the slave trade and of the practice of slavery. He lays the blame for the disruption and degradation of African societies on the slave traders, whom he designates as "Christians." He concludes: "Thus the Christians preach the Gospel to the Heathens!" (Wesley 2007b, 67); having earlier noted that "Whites, not Blacks, are without natural affection!" (Wesley 2007b, 66). He describes the deaths of thousands during the passage to the Americas and declares: "O Earth, O Sea, cover not thou their blood!" (Wesley 2007b, 67). After describing the treatment of enslaved people, he raises the questions: "Did the Creator intend that the noblest creatures in the visible world live such a life as this? Are these thy glorious work, Parent of Good?" (Wesley 2007b, 68). He finishes this section by describing the cruel punishments for enslaved people who resist or seek to escape, as set out in various colonial laws. These laws legalised cruelty and murder, and the lawmakers would be held accountable by God for them. In narrating these laws, Wesley describes the rebellion of enslaved people as "asserting their native liberty, which they have as much right to as to the air they breathe" (Wesley 2007b, 68) and those who seek to escape as engaging in "the most natural act" (Wesley 2007b, 69).

Wesley's ethical argument sets "the Bible out of the question" (Wesley 2007b, 70) and argues that slavery is inherently evil because it is contrary to justice and mercy. Human laws authorising slavery must be judged by the fundamental principles of justice and mercy.

Slave-holding as an institution is inconsistent with "any degree of natural justice" (Wesley 2007b, 70). Practices related to the slave trade and slave holding are unjust as they inflict injury on innocent people. The core of Wesley's argument is that slavery deprives people of their liberty "to which an Angolan has the same natural right as an Englishman" (Wesley 2007b, 70). It is impossible to justly deprive someone of their natural liberty. "Liberty is the right of every human creature, as soon as he breathes the vital air, and no human law can deprive him of that right he derives from the law of nature" (Wesley 2007b, 79). Wesley then insists that the practices involved in enslaving and holding people in slavery are incompatible with mercy.

He rejects the argument that slavery is an economic necessity. Economic necessity cannot justify the violation of fundamental ethical norms. "It is impossible that it should ever be necessary for any reasonable creature to violate all the laws of justice, mercy,

6 Wesley's argument is based on the seminal work of the jurist William Blackstone; see Blackstone $1979,411-412$. 
and truth. No circumstances can make it necessary for a man to burst in sunder all the ties of humanity" (Wesley 2007b, 72).

He rejects the argument that the cruel abuse of enslaved people is necessary to make them work productively. He challenges his "Christian" readers with the question: "When did a Turk or a Heathen find it necessary to use a fellow creature thus?" (Wesley 2007b, 74). The defenders of slavery argued that Africans were stupid, stubborn, and wicked. Wesley counters that: "The inhabitants of Africa ... are not inferior to the inhabitants of Europe; to some of them they are greatly superior" (Wesley 2007b, 74). What the defenders of slavery described as their stupidity, stubbornness and wickedness, were a consequence of enslavement and the enslaved people's response to being enslaved.

He then addresses people who directly perpetrate or benefit from the enslavement of people. $^{7}$ Firstly, he addresses the captains of slave ships. He calls on them to acknowledge the truth about African people and cultures and to take responsibility for the suffering and death that they have caused. He states that he was motivated by love for the enslavers and the enslaved people. He warns them that God is just, and they will face God's judgment. Just as they did not show mercy to others, so God will not show mercy to them. But the God of love calls them and will help them to turn away from evil.

Secondly, he addresses the merchants who own the ships and finance the slave trade. They are responsible for the suffering and death of enslaved people, caused by their money. Wesley calls on them: "Be you a man, not a wolf, a devourer of the human species! Be merciful, that you may obtain mercy" (Wesley 2007b, 78).

Thirdly he addresses the owners of plantations. It is their purchasing of enslaved people that drives the slave trade. They bear responsibility for its "complicated villainy" which is worse than that "ever practised either by Mahometans or Pagans" (Wesley 2007b, 78). The blood of all who die as a consequence of slavery lies on their head. This is: "'The blood of thy brother' (for, whether thou wilt believe it or no, such he is in the sight of Him that made him) 'crieth against thee from the earth,' the ship and from the waters" (Wesley 2007b, 78). They too must show themselves to be "a man" and not be "more savage than a lion or a bear!" (Wesley 2007b, 79). Turning to those who inherited enslaved people, Wesley argues that justice requires that they be given the liberty which

7 Wesley explains why he does not address the British parliament with the statement, "So many things, which seem of greater importance lie before them, that they are not likely to attend to this" (Wesley 2007b, 75). Given the data that he puts forward about the deaths and sufferings of enslaved people, this is devastating critique of the priorities of parliament. Wesley later publicly initiated the campaign of the Society for the Abolition of the Slave Trade to bring about an Act of Parliament that would abolish the slave trade; see Brendlinger 2006, 36-43. 
is the right of all people, based on the law of nature. Liberty is due to all and all are required to do to others as they would have them do to them.

Wesley concludes with a prayer to the "God of love" who loves and has mercy on all God's creatures; who is the father of all human beings; who created all nations of the earth of "one blood"; and who redeemed all by the blood of the Son of God. Wesley calls on God to liberate these oppressed "outcasts of men" (Wesley 2007b, 79) who have no one to help them.

\section{Theological Allusions in Wesley's Anti-slavery Argument}

As argued above, Wesley's theological allusions are significant as they relate his nonreligious argument to his core theological convictions. This will be demonstrated by examining a selection of these allusions.

\section{The God of Love}

Wesley prays: "O thou God of love, thou who art loving to every man, and whose mercy is over all thy works; though who art the Father of the spirits of all flesh, and who art rich in mercy unto all" (Wesley 2007b, 79). This alludes to the central assertion of Wesley's theology that God is love. He comments on 1 John 4:8:

God is often styled holy, righteous, wise; but not holiness, righteousness, or wisdom in the abstract, as he is said to be love; intimating that this is his darling, his reigning attribute, the attribute that sheds an amiable glory on all his other perfections. (Wesley 1976, 914)

Love is "the express image of [God's] person" (Wesley 1987a, 377). This emphasis on God as love and that God loves every human being, comes to the fore in Wesley's arguments against the Calvinist doctrine of election. This, Wesley argues, is irreconcilable with divine love. Wesley regularly refers to Psalm 145:9, "The Lord is

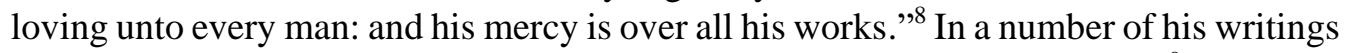
he describes God as the "Parent of good," or the "Parent of all good," the same description he uses in Thoughts upon Slavery to contrast God's intention for humanity and the cruelty experienced by enslaved people. The theological affirmations that are the basis of Wesley's rejection of Calvinism form the theological foundation of his rejection of slavery.

8 See, for example, Wesley 2013, 285, 293 \& 546.

9 This is a quote from John Milton's Paradise Lost (Book 5, line 153), his reference in Thoughts upon Slavery includes a longer quote, turning Milton's statement describing the beauty of Eden: "These are thy glorious work, Parent of Good" (Milton 2000, 105) into the question: "Are these thy glorious work, Parent of Good?" (Wesley 2007b 68). For other uses of the phrase, see for example: Wesley 1984, 692; Wesley 1983, 373; Wesley 1989, 52; Wesley2007a, 67; Wesley 2007b, 13 \& 521. 
The God of love is the compassionate parent of all human beings, the source of all the good they experience, and God desires and works for their well-being. Evil that befalls them is a consequence of sin - either their own or that of others. ${ }^{10}$ In creating human beings, God's intention was their well-being; Wesley describes the unfallen Adam as "unspeakably happy" (Wesley 1985, 397) and proposes that God "made all things to be happy" (Wesley 1987a, 63). Happiness is the enduring satisfaction that is the fruit of having one's deepest desires met. In Thoughts upon Slavery, Wesley contrasts this understanding of God and God's intention to the earthly, bodily suffering experience of enslaved people. The institution of slavery and any defence of it is incompatible with the character and purpose of God.

\section{Justice, Mercy, and Truth}

An appeal to the triad of justice, mercy and truth is central to Wesley's argument. Not only does he refer to them in key places, but his core ethical thesis is that slavery is irreconcilable with justice and mercy. His description of African societies and the cruel realities of slavery is a rejection of the arguments used to defend slavery as deceptive and untrue. This triad regularly occurs throughout Wesley's writings. In some cases, it is a set formula, in other cases he refers only to justice and mercy. ${ }^{11}$

Justice, mercy and truth are a way of summarising the moral character of God. Wesley writes: "Scripture frequently speaks of the glory of God ... meaning thereby the manifestation of his essential glory ... especially his justice, mercy and truth" (Wesley 2013, 289); and "God is full of justice, mercy and truth" (Wesley 1985, 188). Wesley's justice is giving to a person what is due to them for who they are and what they have done. Wesley's understanding of God's justice in relation to human beings is principally judicial and penal - it focuses on God's judgement of sinful human beings. However, God's judgment is always fair; God does not expect from persons what is impossible for them to perform. Wesley writes that God is characterised by "unblemished justice and truth; but above all is his mercy" (Wesley 1987a, 62). Mercy "obliges" God to act in particular ways (Wesley 2015, 9), it requires God to work for the good of God's creatures and to save them from suffering. Mercy arises from God's love, and promotes the flourishing of human beings beyond what justice demands. Truth refers to God's faithfulness and trustworthiness. There is tension in Wesley's understanding of these three characteristics and how they relate to love as the defining attribute of God. Love, and therefore mercy, has priority (Wesley 2013, 284). God desires to save human beings but if they habitually reject God's work, they will be judged for their sin.

Wesley pleads for God, out of God's rich mercy, to liberate enslaved people. He emphasises, however, that those who enslave others and those who hold them in slavery will be judged by God for their cruelty toward their fellow human beings. God in mercy

10 For Wesley, natural evil was a consequence of the fall which God permits and uses for the greater good of human beings; see Wesley 1985, 423-435.

11 See Gale 2016 
calls on them to repent from their oppressive ways. This is also an expression of mercy to enslaved people who would be freed from slavery when the enslavers repent.

Human beings are created in the moral image of God and they are, therefore, created to live lives of justice, mercy and truth. In human beings, justice, mercy and truth are expressions of love for one's neighbour. Justice is treating other human beings as "being made in the image of God, bought by his Son, and designed for his kingdom" (Wesley 1976, 879). Mercy goes beyond justice and responds to human beings in their need and misery; it seeks to meet their needs, and relieve their misery. Both mercy and justice are expressions of the Golden Rule of doing to others as you would have them do to you. Truth is the manifestation of love that rejects all forms of deceit and is expressed in reliability, integrity and honesty.

While, in Wesley's understanding, human beings lost the moral image of God through the fall, God partially restores it through prevenient grace. This means that all human beings are aware of the basic moral standard of the Golden Rule, which ought to be expressed in personal and social behaviour characterised by justice, mercy and truth (Wesley 1984, 660-661). These virtues become Wesley's universal standards for evaluating and critiquing societies, cultures and institutions.

The experience of the new birth, growth in sanctification, and the endowment of Christian perfection are intensifications of the restoration of the moral image of God and should thus lead to greater and deeper expressions of justice, mercy and truth. This was central to the identity and mission of Methodism in Wesley's time. He thus describes the mission of Methodism as: "We unite together for this and no other endto promote, as far as we are capable, justice, mercy and truth, the glory of God, and peace and goodwill among men" (Wesley 1987b, 105). If slavery is incompatible with justice, mercy and truth, it is incompatible with the Methodist identity and mission.

\section{All Human Beings are Equal Siblings}

At key places in the argument, we find allusions to the story of Cain and Abel. The shed blood of the enslaved people cries out for justice, as the blood of Cain and Abel did. More than that, the enslaved people and the enslavers are "brothers"-children of the same creator. The final prayer, referring to Acts 17:26, describes God as having "mingled of one blood all the nations upon the earth"; here mingled has its eighteenthcentury meanings of united or composed. Hence, all nations of the world are part of the same family.

This emphasis on the common "brotherhood" of humanity is not common in Wesley's writings. Importantly, it does occur in the defence of his understanding of the Christian faith in An Ernest Appeal to Men of Reason and Religion, where he states:

Is it not reasonable also to love our neighbour: every man whom God hath made? Are we not brethren? The children of one father? Ought we not then to love one another? 
And should we only love them that love us? Is that acting like our Father which is in heaven? He causeth "his sun to shine on the evil and on the good, and sendeth rain on the just and on the unjust." And can there be a more equitable rule than, "Thou shalt love thy neighbour as thyself?" You will plead for the reasonableness of this, as also for that golden rule, (the only adequate measure of brotherly love, in all our words and actions), "Whatsoever ye would that men should do unto you, even so do unto them." (Wesley 1989, 52)

He refers to this theme explicitly in other texts dealing with slavery and with the cruelties inflicted on the indigenous inhabitants of India and America by colonial conquest. ${ }^{12} \mathrm{He}$ also comments on Acts 17:26: "By this expression the apostle showed them ... that ... he was not enslaved to any narrow views, but looked on all mankind as his brethren" (Wesley 1976, 465). Commenting on the parable of the Good Samaritan, he states: "let us always remember that kindred between man and man, and cultivate that happy instinct whereby, in the original constitution of our nature, God has strongly bound us to each other" (Wesley 1976, 242).

These explicit references cohere with the understanding of the character of God described above. In his closing prayer, Wesley describes God as "the Father of the spirits of all flesh" (a combination of Numbers 16:22 and Hebrews 12:9). This description of God occurs in other contexts where he emphasises God's concern for all human beings. He thus affirms that: "'The Father of the spirits of all flesh' ... is the God of the heathens as well as the Christians, and who hateth nothing that he hath made" (Wesley 1987a, 174). He uses this phrase to assert the universal extent of neighbourly love, stating: "If any man ask, 'Who is my neighbour?' we reply, every man in the world; every child of his who is "the Father of the spirits of all flesh"' (Wesley 1984, 137-138). He comments on the Lord's Prayer:

"Our Father:"-Not mine only who now cry unto him, but ours in the most extensive sense. The "God and Father of the spirits of all flesh"; the Father of angels and men ... the Father of the universe, of all the families both in heaven and earth. Therefore, with him there is no respect of persons. He loveth all that he hath made. He "is loving unto every man, and his mercy is over all his works" ... But "if God so loved us, we ought also to love one another." Yea, all mankind; seeing "God so loved the world, that he gave his only-begotten Son" ... that they "might not perish, but have everlasting life." (Wesley 1984, 579)

All human beings, regardless of national origin, culture, or religion are all children of the same Parent of Good and, therefore, siblings with a responsibility to care for each other. In contrast, Wesley's contemporary, the Enlightenment philosopher David Hume, (1711-1776) writes: "I am apt to suspect that the negroes and in general all of the other

12 See Wesley 2007b, 125-126 \& 145. 
species of men (for there are four or five different kinds) to be naturally inferior to the whites" (Hume 1826, 236). ${ }^{13}$

As equal siblings who have all fallen into sin and who all experience prevenient grace, all human beings have the same potential for good and evil. No ethnic or national group is inherently superior to another. All have the potential for ethical excellence or depravity, depending on their response to divine grace. Despite the influence of Christianity, the European participation in slavery demonstrates their rejection of grace, while West-African cultures accept the influence of prevenient grace experienced in their own religious traditions, and therefore display greater intensities of justice, mercy and truth.

Wesley's description of the moral integrity of African societies, and relating this to their worship of God, correlates with the statement in his sermon "Salvation by Faith," where he describes the "faith of a heathen":

Now God requireth of a heathen to believe "that God is, and that he is a rewarder of them that diligently seek him" and that he is to be sought by "glorifying him as God by giving him thanks for all things," and by a careful practice of moral virtue, of justice, mercy and truth, toward their fellow-creatures. (Wesley 1984, 119)

Such persons did not experience the full blessings of salvation experiences by Christians, but they were accepted by God. There was thus no urgency to bring them as slaves to America so that they could hear the gospel, as argued by some supporters of slavery. ${ }^{14}$

\section{Liberty}

Wesley asserts that all human beings have a right to natural liberty; it is fundamentally unjust to deprive them of this through enslavement, and resistance to slavery is an expression of this natural liberty. The theme of liberty was prominent in the intellectual and political discourse of eighteenth-century Britain and in the British colonies in America. Wesley discusses it in a number of tracts responding to political conflicts in Britain and to the American Revolution. In these writings he argues that "natural liberty"

13 Hume went on to assert: "There never was a civilized nation of any other complexion than white, nor even any individual eminent either in action or speculation. No ingenious manufactures amongst them, no arts, no sciences. On the other hand, the most rude and barbarous of the whites, such as the ancient GERMANS, the present TARTARS, have still something eminent about them, in their valour, form of government, or some other particular. Such a uniform and constant difference could not happen in so many countries and ages, if nature had not made an original distinction betwixt these breeds of men. Not to mention our colonies, there are NEGROE slaves dispersed all over EUROPE, of which none ever discovered any symptoms of ingenuity, tho' low people, without education, will start up amongst us, and distinguish themselves in every profession. In JAMAICA indeed they talk of one negroe as a man of parts and learning, but 'tis likely he is admired for very slender accomplishments like a parrot, who speaks a few words plainly" (Hume 1826, 236).

14 See his detailed comments on the story of Cornelius in Acts 10:35, in Wesley 1976, 434-435. 
is an inherent component of what it means to be human. While the socio-political tracts are an important resource for reconstructing Wesley's concept of liberty, they do not provide a theological basis for his assertion. In order to understand the theological context of his concept of liberty and, hence, his argument against slavery, his statements need to be interpreted in relation to his theological core.

Wesley's tract, Thoughts upon Liberty, begins with the assertion that:

All men in the world desire liberty; whoever breathes, breathes after this, and that by a kind of natural instinct antecedent of art, of education. Yet at the same time all men of understanding acknowledge it is a rational desire. For we feel this desire, not in opposition to, but in consequence of, our reason. (Wesley 2007b, 35)

Wesley defines this "liberty" as having two components; religious liberty and civil liberty. In A Calm Address to Our American Colonies, he argues that it is the possession of these liberties that distinguishes a free person from an enslaved person (Wesley 2007b, 81). ${ }^{15}$

Religious liberty is "a liberty to choose our own religion, to worship God according to our own conscience according to the best light we have" (Wesley 2007b, 37). This right was given to every human being by God. "Consequently, this is an indefeasible right; it is inseparable from humanity." No one has the authority to deprive someone of this right. It is of fundamental theological significance "because every man must give an account of himself to God" (Wesley 2007b, 92; cf. 1989, 50).

Human responsibility and accountability before God are fundamental to Wesley's theology. He developed his most detailed defence of this understanding in his debate with the Calvinists. ${ }^{16}$ In this context he cited biblical texts where people were challenged to obey God and warned of God's judgment on disobedience. Such passages require that persons have the ability to make genuine choices for which they are responsible to God and that such choices are not predetermined by God. God is just and it would be unjust for God to condemn people for actions that they had not responsibly chosen to do. Hence, Wesley argues that human beings are free to choose between different options and to choose to obey or not to obey God's commands. He thus concludes that all human beings have a faculty that enables them to make free and responsible choices. This is the faculty of liberty, which Wesley identified as a component of the natural image of God. ${ }^{17}$ To be human, is to have liberty, and no one has the right to prevent one

15 Similarly, in Observations on Liberty, he describes slavery as "a state wherein neither a man's goods, nor liberty, nor life, are at his own disposal" (Wesley 2007b, 109).

16 See Predestination Calmly Considered, Works (Wesley 2013, 261-320) and Thoughts Upon (Wesley 2013, 528-546).

17 See the discussion in Kim 2006, 34-39 and Browder 2020, 37-77. 
from exercising this liberty of making free and responsible choices about one's relationship with God. Hence, all human beings have a natural right to religious liberty.

The second component is civil liberty; that is the "liberty to dispose of our lives, persons and fortunes, according to our choices and the laws of our country" (Wesley 2007b, 92). ${ }^{18}$ Wesley does not provide an explicit theological basis for civil liberties, though he does describe them as "the gift of God." ${ }^{19}$ However, following the example of his argument that religious liberty is rooted in human responsibility before God, it is possible to argue that he also understood civil liberty as rooted in human responsibility before God - and thus as an expression of the natural image of God.

The foundation for this argument lies in the seventeenth and eighteenth-century understandings of natural rights being rooted in what inherently belongs to a person by virtue of the person being human. ${ }^{20}$ Wesley's interpretation of what belongs to a person is developed in his theology of stewardship. In his sermon "The Good Steward" (Wesley 1985, 282-298), he argues that God has entrusted us with our souls, our bodies, (including our tongues and hence our speech, and our hands and feet and hence our actions), our worldly goods and our talents. We are responsible to God for the way that we use them. Analogous to Wesley's argument for religious liberty, it is possible that Wesley understood that if we are to act as responsible agents before God, we must be able to freely dispose of our souls, bodies, worldly goods and talents. Civil liberty is the guarantee of our ability to responsibly use our bodies, possessions and talents for the good of others. When some abuse their rights to the detriment of others, then the government has the duty - as the agent of God's justice - to limit these rights. While Wesley does not develop this argument, it is consistent with his theology and may lie behind his understanding of civil liberties as part of natural liberty.

Slavery deprives a person of religious and civil liberties by putting a person under the power of the enslaver, so that the enslaver controls the person's decisions, preventing them from acting responsibly in the world. Wesley's appeal to natural liberty as an argument against slavery is thus rooted in his fundamental theological conviction that human beings are responsible before God's judgment for the way they act. Wesley's insistence on the right to liberty for Africans is rooted in recognition of their common equal humanity as siblings created in the image of God. This was not (in the time of Wesley) a recognition shared by all. In the seventeenth century, independent slave

18 The recognition that natural liberty is constrained by law is also found in other writers of the time; see Locke 2003, 109-110.

19 In his notes on Acts 22:28, where he states "we are under no obligation as Christians to give up our civil privileges (which we are to receive and prize as the gift of God) to every insolent invader. In a thousand circumstances, gratitude to God, and duty to men, will oblige us to insist upon them; and engage us to strive to transmit them improved, rather than impaired to posterity" (Wesley 1976, 488).

20 This is extensively discussed by Stephen Buckle; it must be noted that what belongs to someone is not private property as defined by positive law but refers to one's life, body and liberty. Legally defined private property is an extension of this; see Buckle 1991, 28-31. 
traders challenged the legal monopoly of the Royal African Company on the grounds that English liberty required that all English people had the right to engage in the slave trade. $^{21}$

\section{Natural Law}

Wesley appeals not only to natural liberty, but also to natural law and in some cases proposes that the affirmation of liberty arises out of natural law. The concept of natural law has a long history in Christian and non-Christian thought, and in Wesley's time it was applied to develop a theoretical basis for the limitation of the power of governments. Wesley's appeal to natural law would have resonated with a secular audience. However, Wesley had a developed theology of law including natural law, which suggests a particular way of interpreting his assertions.

Wesley proposes that the moral law of God is the expression of the character of God in a way which is appropriate for creatures to see and understand. It explains what God requires of them if they are to imitate the character of God in their contexts and relationships. ${ }^{22}$ As God is "the great ocean of love" (Wesley 1985, 39), the whole of moral law "is comprised in one word-Imitate the God of love" (Wesley 1984, 42). The origin, centre and goal of the moral law is love for God and our neighbours. ${ }^{23}$ Human beings were created in the moral image of God; that is, they were created with a knowledge of the moral law of God in the depths of their being. However, the consequence of human sin is that this knowledge of the moral law is erased from within the human person. But, in prevenient grace, God has "in some measure re-inscribed the law on the heart of his dark, sinful creature" (Wesley 1985, 7). ${ }^{24}$ This is what Wesley means by "natural law."

The content of natural law for our relationships with other human beings is "that glorious rule of mercy as well as justice ... Whatsoever ye would that men should do unto you, the same do unto them" (Wesley 1986, 352). ${ }^{25}$ This is "a rule many believe to be naturally engraved on the mind of everyone that comes into the world" (Wesley 1984, 661). In various contexts, Wesley expands this with the triad of justice, mercy and truth. Human beings discover what natural law is as they relate these fundamental principles to particular contexts and relationships. Wesley's understanding of grace is dynamic and interactive. In any given person or society there is a complex and active relationship between grace and sin; thus, the awareness and implementation of God's moral requirements vary in diverse societies. Natural law is a preliminary and partial awareness of the moral law, which was more fully revealed in the moral command of the Old Testament and most completely revealed in the person, life and teaching of

21 See Pettigrew, 2013.

22 See Wesley 1985, 9.

23 See Wesley 1984, 542; Wesley 1987a, 332; Wesley 1987b, 203.

24 See also Wesley 1986, 199 \& 200.

25 See his exposition of this in Wesley 1984, 660-663. 
Christ. Natural law does not provide additional moral instruction to Christologically revealed moral law.

To argue that slavery is contrary to natural law, Wesley is arguing that it is contrary to the widely recognised principle of "doing unto others as you would have them do to you" (Wesley 2007b 79), which requires that all people act with justice and mercy to other people. This requires of those who were passionate about their own liberty, as the English and the American colonists were, that they should also be passionate about the liberty of enslaved Africans. The implication is also that those who have a fuller understanding of the moral law, ought to implement justice and mercy at greater depth and breadth, which is precisely what Wesley accuses the "Christian" societies of failing to do.

\title{
Motivated by Love
}

Wesley proposes that his motivation for writing Thoughts upon Slavery is his love for enslaved people and for their enslavers. This might appear to be a rather banal statement, if the place of love in Wesley's understanding of salvation is not recognised. Salvation is the process by which human beings are transformed into the image of God; so that lives become permeated by divine love; so that all their relationships with other human beings are characterised by justice, mercy and truth. This begins with the new birth, grows in depth and breadth through sanctification and reaches a new intensity through Christian perfection. The goal of the Christian life is to be like boiling water "penetrated and heated by the fire of love" (Wesley 1976, 952). He describes it in more detail:

\begin{abstract}
Above all, remembering that God is love, he is conformed to the same likeness. He is full of love to his neighbour; of universal love; not confined to one sect or party; not restrained to those who agree with him in opinions, or in outward modes of worship; or to those who are allied to him by blood, or recommended by nearness of place. Neither does he love those only that love him, or that are endeared to him by intimacy of acquaintance. But his love resembles that of Him whose mercy is over all His works. It soars above all these scanty bounds, embracing neighbours and strangers, friends and enemies; yea, not only the good and gentle, but also the forward, the evil and unthankful. For he loves every soul that God has made; every child of man, of whatever place or nation. (Wesley 2007a, 68)
\end{abstract}

Such love is manifested in a deep commitment to the well-being of enslaved people, passionate rejection of slavery, and engagement to end it; and at the same time a desire that enslavers are transformed so that they turn away from injustice and cruelty.

\section{Wesley's Argument in Context}

The significance of Wesley's theological opposition to slavery must be seen within the context in which Wesley wrote. At the time of writing, Wesley was a prominent, if controversial, figure within the Church of England. He was one of the first prominent church leaders to not only condemn the slave trade and the cruel treatment of enslaved 
people, but also to reject slavery as an institution as fundamentally evil. This is particularly noteworthy in that the Church of England was itself deeply compromised due to its entanglements with slavery (see Glasson 2012).

Wesley was a member of Britain's educated elite; he was a graduate of Oxford University and as a consequence, was a member of the minority who had the right to vote for the British parliament. Thoughts upon Slavery, with its argument based on natural law and liberty, reflects the discourse of this elite even when it was written for a more popular readership. However, unlike most members of the elite, he had personally encountered slavery and enslaved people during his stay in America. It is probable that this personal experience-combined with his already developed understanding of the centrality of love within the Christian faith, expressed in a commitment to relieving the needs of the poor and marginalised-was an important contributor to his developing opposition to slavery.

Wesley wrote Thoughts upon Slavery before the major struggle against the slave trade with its "pamphlet war" began in the 1780 s. ${ }^{26}$ However, he did draw on the work of the emerging voices against slavery; notably the writings of the Quaker, Anthony Benezet. Yet, the core of his argument from natural law and liberty and the theological allusions are his own. ${ }^{27}$ This is important in that Wesley's argument opens an alternative to the theological arguments used both for and against slavery prior to and after Wesley. These arguments focused on the quotation and interpretation of biblical texts. ${ }^{28}$ Wesley's deliberately setting "the Bible out of the question" (Wesley 2007b, 70) is particularly significant, as George Whitefield wrote a letter to Wesley in 1751 defending his views on slavery using various biblical texts (Brendlinger 2006a, 56-58). Wesley does not give reasons for his decision in this regard. In part, it appears that he is seeking to address a broader public. However, it might have been a way to avoid the struggle over the interpretation of texts that were used to support slavery. Whatever Wesley's motivation was, his approach, with its use of non-religious language and theology that lies behind the allusions in the texts, suggests a more fruitful way to address the issue than the appeals to the Bible. Advocating for the abolition of slavery from the Bible required focusing on particular biblical texts and themes, and ignoring or radically reinterpreting others. Such an approach has importance in particular contexts, as Emerson Powery and Rodney Sadler demonstrate in their study of texts written by people who had been enslaved in nineteenth-century America (Powery and Sadler 2016). It, however, has the danger of merely using the Bible to justify positions that have other sources (Avalos 2011, 236-250 and 269-288). Wesley's approach moves beyond struggles over the meaning of particular texts that arise out of and address particular ancient contexts, and focuses on the central theological core of the Christian faith. In this way, it opens the

26 For information on and pamphlets from both sides from the 1780s, see Pinfold 2007.

27 For information on Wesley's argument, see Baker 1984 and Smith 1986, 90-97.

28 See Benezet, A Short Account of the Part of Africa Inhabited by the Negros and Some Historical Account of Guinea, in Brendlinger 2006b, 123-135 and 137-204; and for other examples: An African Merchant 1772; Godwyn 1680; Seewall 1700; Sharp 1773; Thomson n.d.; and Woolman 1754. 
way for a hermeneutical approach that addresses biblical texts from the perspective of what is understood as the central message of the Bible.

\section{Conclusion}

This article has sought to demonstrate that the theological allusions in Wesley's Thoughts upon Slavery are not random throw-away phrases, but references to key elements of core theological convictions. Given the theological differences that Wesley had with the Calvinist, George Whitefield, it is significant that some of the same convictions that motivated Wesley's rejection of the Calvinist doctrine of election, reoccur in his rejection of slavery. More importantly, the core of Wesley's theology is that salvation is the process by which a person is transformed into the image of the God of mercy and justice; as such, to argue that slavery is contrary to justice and mercy, is to argue that involvement in slavery is contrary to what it means to experience salvation. One of the tragedies of Methodist history is that significant numbers of Methodists have not recognised this. In America, many turned to Biblicist arguments to justify slavery. In other contexts, not the least in colonial and apartheid South Africa, some Methodists have seen no contradiction between Methodism and supporting systematic cruelty and injustice. It must be noted that while maintaining the equality of all human beings, in other rhetorical contexts - particularly when dealing with human sin-Wesley exhibits many of the cultural prejudices and superiority complexes of his contemporaries. ${ }^{29}$

In the context of contemporary anti-racist protests, the example of Wesley's opposition to slavery should not become a tool of a self-serving claim to innocence, by his theological descendants, but should be a challenge to work out in diverse contexts what it means to be transformed into the image of the God of mercy and justice.

\section{Autobiography}

The author is a research associate at the Research Institute for Theology and Religion, University of South Africa, and an academic coordinator at the Methodist e-Academy.

\section{References}

An African Merchant. 1772. A Treatise upon the Trade from Great Britain to Africa. London: R. Baldwin.

Avalos, H. 2011. Slavery, Abolitionism and the Ethics of Biblical Scholarship. Sheffield: Sheffield Phoenix.

Baker, F. 1984. “The Origins, Character and Influence of John Wesley's Thoughts upon Slavery." Methodist History 22: 75-86.

29 See Wesley 2012, 175-186. 
Blackstone, W. 1979. Commentaries on the Laws of England: Facsimile of the First Edition 1765-1769, Volume 1, Of the Rights of Persons, Chicago and London: University of Chicago Press. https://doi.org/10.7208/chicago/9780226161037.001.0001.

Brendlinger, I. A. 2006a. Social Justice through the Eyes of Wesley: John Wesley's Theological Challenge to Slavery. Ontario: Joshua Press.

Brendlinger, I. A. 2006b. To be Silent ... Would be Criminal: The Antislavery Life and Writings of Anthony Benezet. Lanham: Scarecrow.

Browder, M. H. 2020. Heart Ethics: Pursuing Christian Love According to the Theology of John Wesley. Lexington: Emeth.

Buckle, S. 1991. Natural Law and the Theory of Property: Grotius to Hume. Oxford Clarendon.

Collins, K. J. 2007. The Theology of John Wesley: Holy Love and the Shape of Grace. Nashville: Abingdon.

Field, D. N. 2015. "John Wesley as a Public Theologian: The Case of Thoughts upon Slavery." Scriptura 114: 1-13. http://scriptura.journals.ac.za/pub/article/view/1136/1081. https://doi.org/10.7833/114-0-1136.

Gale, M. A. 2016, “'Justice, Mercy, and Truth,' A Theological Concept in the Sermons of John Wesley." Wesleyan Theological Journal 51 (2): 109-124.

Godwyn, M. 1680. The Negro and Indians Advocate Suing for their Admission into the Church. London: F.D.

Glasson, T. 2012. Mastering Christianity: Missionary Anglicanism and Slavery in the Atlantic World. Oxford: Oxford University Press. https://doi.org/10.1093/acprof:oso/9780199773961.001.0001.

Hume, D. 1826. The Philosophical Works, Vol. III. Edinburgh: Adam Black and William Tait,

Kim, Y. T. 2006. “John Wesley's Anthropology: The Restoration of the Imago Dei as a Framework Wesley's Theology.” PhD. Dissertation: Drew University.

Locke, J. 2003. Two Treatises of Government and A Letter Concerning Toleration. New Haven: Yale University Press.

Maddox, R. L. 1994. Responsible Grace: John Wesley's Practical Theology. Nashville, Abingdon.

Marquardt, M. 1992. John Wesley's Social Ethics: Praxis and Principles. Nashville, Abingdon.

Marquardt, M. 2008. Praxis und Prinzipien der Sozialethik John Wesleys. Göttingen, Edition Ruprecht. 
Milton, J. 2000. Paradise Lost. London: Penguin.

O'Brien, G. 2018. "Freedom in the Atlantic World: John Wesley and George Whitefield on Slavery." Wesley and Whitefield: Wesley versus Whitefield, edited by I. J. Maddock, 161182. Eugene: Pickwick.

Pettigrew, W. A. 2013. Freedom's Debt: The Royal African Company and the Politics of the Atlantic Slave Trade, 1672-1752. Chapel Hill: University of North Carolina Press. https://doi.org/10.5149/northcarolina/9781469611815.001.0001.

Pinfold, J. 2007. The Slave Trade: Contemporary Writings for and Against. Oxford: Bodleian Library.

Powery, E. B., and R. S. Sadler. 2016. The Genesis of Liberation: Biblical Interpretation in the Antebellum Narratives of the Enslaved. Louisville: Westminster John Knox.

Seewall, S. 1700. The Selling of Joseph: A Memorial. Boston: Green and Allen.

Sharp, G. 1773. An Essay on Slavery Proving from Scripture its Inconsistency with Humanity and Religion. Burlington: Isaac Collins.

Stone, R. H. 2001. John Wesley's life and Ethics, Nashville, Abingdon.

Smith, W. T. 1986. John Wesley and Slavery. Nashville, Abingdon.

Suray, J. B. 2015. Towards a Theology of Universality: John Wesley's Socio-Economic, Political and Moral Insights on British Class and Indian Caste Distinctions. New Dehli, Christian World Imprints.

Thompson, T. n.d. The African Trade for Negro Slaves, Shewn to be Consistent with the Principles of Humanity and the Laws of Revealed Religion. Simmons and Kirkby.

Wesley, J. 1976. Explanatory Notes upon the New Testament. Peterborough, Epworth.

Wesley, J. 1983. The Works of John Wesley (Bicentennial Edition), Vol. 7 A Collection of Hymns for the People Called Methodist. Nashville: Abingdon.

Wesley, J. 1984. The Works of John Wesley (Bicentennial Edition), Vol. 1 Sermon I. Nashville: Abingdon.

Wesley, J. 1985. The Works of John Wesley (Bicentennial Edition), Vol. 2 Sermons II. Nashville: Abingdon.

Wesley, J. 1986. The Works of John Wesley (Bicentennial Edition), Vol. 3 Sermons III. Nashville: Abingdon. 
Wesley, J. 1987a. The Works of John Wesley (Bicentennial Edition), Vol. 4 Sermons IV. Nashville: Abingdon.

Wesley, J. 1987b. The Works of John Wesley (Bicentennial Edition), Vol. 26 Letters II 17401755. Nashville: Abingdon.

Wesley, J. 1989. The Works of John Wesley (Bicentennial Edition), Vol. 11 The Appeals to Men of Reason and Religion and Certain related Open Letters. Nashville: Abingdon.

Wesley, J. 2003. The Works of John Wesley (Bicentennial Edition), Vol. 24 Journal and Diaries 7 (1787-1791). Nashville: Abingdon.

Wesley, J. 2007a. The Works of the Rev. John Wesley, M.A. (Jackson Edition), Vol. 10. Grand Rapids: Baker Book House.

Wesley, J. 2007b. The Works of the Rev. John Wesley, M.A. (Jackson Edition), Vol. 11. Grand Rapids: Baker Book House.

Wesley, J. 2012. The Works of John Wesley (Bicentennial Edition), Vol. 12, Doctrinal and Controversial Treatises I. Nashville: Abingdon.

Wesley, J. 2013. The Works of John Wesley (Bicentennial Edition), Vol. 13, Doctrinal and Controversial Treatises II. Nashville: Abingdon.

Wesley, J. 2015. The Works of John Wesley (Bicentennial Edition), Vol. 27, Letters III 17561765. Nashville: Abingdon.

Woolman. J. 1754. Considerations on the Keeping of Negroes. Philadelphia: Tract Association of Friends. 